\title{
Sensory profile and evaluation of the degree of acceptability of bread produced with inulin and oligofructose
}

\author{
Perfil sensorial e avaliação do grau de aceitação de pães produzidos com inulina e \\ oligofrutose
}

\author{
Patricia Kelli de Souza-Borges ${ }^{1}$, Ana Carolina Conti-Silva ${ }^{1 *}$ \\ ${ }^{1}$ Universidade Estadual Paulista (UNESP), Instituto de Biociências, Letras e Ciências Exatas (IBILCE), Departamento de Engenharia e Tecnologia \\ de Alimentos, São José do Rio Preto/SP - Brazil
}

\section{*Corresponding Author}

Ana Carolina Conti-Silva, Universidade Estadual Paulista (UNESP), Instituto de Biociências, Letras e Ciências Exatas (IBILCE), Departamento de Engenharia e Tecnologia de Alimentos, Rua Cristóvão Colombo, 2265, CEP: 15054-000, São José do Rio Preto/SP - Brazil, e-mail: contisil@ibilce.unesp.br

Cite as: Sensory profile and evaluation of the degree of acceptability of bread produced with inulin and oligofructose. Braz. J. Food Technol., v. 21, e2016040, 2018.

\section{Abstract}

Homemade bread was produced with 4.4 and $4.45 \mathrm{~g}$ of total fructans per $50 \mathrm{~g}$ serving to meet Brazilian standards for prebiotic claims. The bread samples were characterized for their sensory profiles using descriptive analysis and for their sensory acceptability using hedonic and just-about-right scales for sweetness intensity. The sensory profiles of the breads were similar and sweetness was the term that discriminated the bread samples obtained, since the intensity decreased from the bread formulated with oligofructose/inulin to the bread formulated with inulin and finally to the standard bread formulation. Comparing the crust colour of the standard bread with the crust colour of the bread with inulin, the bread with inulin was more beige, while the bread with oligofructose/inulin had smaller bubbles and was not as soft. The bread with oligofructose/inulin had a higher degree of acceptability with respect to flavour and overall acceptability than the standard bread, but the bread with fructans was preferred as compared to the standard bread in terms of appearance, aroma, texture, flavour and overall acceptability. In conclusion, the addition of fructans to bread formulations is promising and may promote the elaboration and consumption of new prebiotic products in the bakery line.

Keywords: Descriptive analysis; Just-about-right scale; Internal preference mapping.

\section{Resumo}

Pães caseiros foram produzidos com quantidades de 4,4 e 4,45 g de frutanos totais por porção de $50 \mathrm{~g}$, para atendimento da alegação de prebióticos, segundo a legislação brasileira. Os pães foram caracterizados, quanto ao perfil sensorial, por meio de análise descritiva, e quanto aos testes de aceitação sensorial, utilizando escala hedônica e escala do ideal para intensidade de doçura. Os perfis sensoriais dos pães mostraram-se similares, sendo a doçura o termo que discriminou os pães obtidos, visto que as intensidades diminuíram na formulação dos pães com oligofrutose/inulina para a formulação dos pães com inulina e para a formulação dos pães padrão. Comparando a cor da crosta do pão padrão com a cor da crosta do pão com inulina, o pão com inulina apresentou maior intensidade de cor bege, enquanto que o pão com oligofrutose/inulina teve menor tamanho de bolhas e maciez. O pão com oligofrutose/inulina teve maior grau de aceitação para o sabor e de forma global em relação ao pão padrão, mas as formulações dos pães com frutanos foram preferidos em relação à formulação do pão padrão para aparência, aroma, textura, sabor e aceitação global. Concluindo, a adição de frutanos em formulações de pães é promissora, podendo promover a elaboração e consumo de novos produtos prebióticos na linha de panificação.

Palavras-chave: Análise descritiva; Escala do ideal; Mapa de preferência interno. 


\section{Introduction}

Prebiotics are food compounds that cannot be digested by the enzymes of the human gastrointestinal tract and therefore behave like fibres. They are fermented within the large intestine by desirable colon bacteria such as bifidobacteria and lactobacilli (probiotics). This process produces lactic acid, short chain fatty acids (acetic, propionic and butyric), and gases, favouring the reduction of the intestinal $\mathrm{pH}$ and inhibiting the proliferation of harmful microorganisms (GIBSON; ROBERFROID, 1995; WANG, 2009). The main prebiotics available and used by the food industry worldwide belong to the carbohydrate group, including isomalto-oligosaccharides, trans galacto-oligosaccharides, fructo-oligosaccharides and inulin (SIRÓ et al., 2008). The latter two have been studied more frequently, and are the prebiotics that have been approved by the Brazilian Health Surveillance Agency (ANVISA, 2016) because of their contributions to the balance of the intestinal microbiota.

Inulin and oligofructose are prebiotics that belong to a class of carbohydrates called fructans, a generic term that is used to describe fructose oligo- and polysaccharides of vegetable origin (CARABIN; FLAMM, 1999). Inulin is a storage carbohydrate found in chicory roots (Cichorium intybus) and Jerusalem artichoke (Helianthus tuberosus). Structurally, it is composed of $\beta$-D-fructofuranose polymers joined by $\beta(2 \rightarrow 1)$ bonds, with a degree of polymerization of up to 70 (ROBERFROID; DELZENNE, 1998). Oligofructose is obtained from the partial hydrolysis of chicory inulin with subsequent purification, and its degree of polymerization ranges from 2 to 8 (ROBERFROID, 2005).

Fructans have been used in foods such as dairy-based beverages, fruit beverages, and bakery products. Although the addition of fructans to bakery products has been extensively researched because of their stability during storage, and also because the sensory aspects are not negatively affected after the addition of these substances (LAMSAL; FAUBION, 2009), there are few studies on the addition of inulin, oligofructose or fructo-oligosaccharides to bread (CAPRILES; ARÊAS, 2013; KORUS et al., 2006; O'BRIEN et al., 2003). Moreover, considering that consumers are not interested in buying functional products if the added ingredients promote strange or unpleasant flavours, even when health benefits are taken into consideration (TUORILA; CARDELLO, 2002), the development of new products is a constant challenge since there are several aspects to be considered, including convenience, quality, savings, variety, and in particular, the nutritional and sensory factors (JOUSSE, 2008).

Thus, given the importance of studies about the addition of fructans as prebiotics to products such as bread, and because of the need for more information on the sensory aspects of these products, the present study sought to elaborate bread containing inulin and oligofructose/inulin and to investigate the sensory profiles and acceptability of these products containing different quantities of total fructans, referred to as potential prebiotics.

\section{Material and methods}

\subsection{Materials}

The fructans Orafti ${ }^{\circledR} \mathrm{GR}$ and Orafti ${ }^{\circledR}$ Synergy 1 were provided by Beneo-Orafti, a Belgian company that extracts and produces inulin and oligofructose. Orafti ${ }^{\circledR} \mathrm{GR}$ is composed of $\geq 90 / 100 \mathrm{~g}$ of inulin (average degree of polymerization $\geq 10$ ) and $\leq 10 / 100 \mathrm{~g}$ of glucose + fructose + sucrose. Orafti ${ }^{\circledR}$ Synergy 1 is composed of approximately $46 / 100 \mathrm{~g}$ of oligofructose, 46/100 $\mathrm{g}$ of inulin and 8/100 $\mathrm{g}$ of glucose + fructose + sucrose. The manufacturers did not provide the degrees of polymerization of the inulin or oligofructose present in Orafti ${ }^{\circledR S y n e r g y} 1$. In the present study, bread elaborated with Orafti ${ }^{\circledR} \mathrm{GR}$ was referred to as bread with inulin, while bread made with Orafti ${ }^{\circledR}$ Synergy 1 was referred to as bread with oligofructose/inulin.

The other ingredients used in the bread formulations (wheat flour, whole milk, soybean oil, refined sugar, biological yeast, refined salt, and egg) were purchased in a local market (in the city of São José do Rio Preto, Brazil). The same brands were used for all formulations.

\subsection{Bread processing}

A standard homemade bread recipe without fructans was used. The other bread samples were developed containing sufficient quantities of inulin and oligofructose/inulin to obtain a minimum of $3 \mathrm{~g}$ of fructans per $50 \mathrm{~g}$ serving in order to comply with Brazilian legislation for prebiotic claims (ANVISA, 2016). The formulations (Table 1) and preparation methods were developed by Souza-Borges et al. (2013), who presented bread with inulin and oligofructose/inulin with 4.4 and $4.45 \mathrm{~g}$ of total fructans per $50 \mathrm{~g}$ serving.

Table 1. Formulations of the standard bread, bread with inulin and bread with oligofructose/inulin.

\begin{tabular}{|cccc|}
\hline Ingredients & Standard & Inulin & $\begin{array}{c}\text { Oligofructose/ } \\
\text { Inulin }\end{array}$ \\
\hline Wheat flour $(\mathrm{g})$ & 650 & 650 & 650 \\
Whole milk $(\mathrm{mL})$ & 230 & 230 & 230 \\
Soy oil $(\mathrm{mL})$ & 150 & 150 & 150 \\
Refined sugar $(\mathrm{g})$ & 75 & 75 & 75 \\
Biological yeast $(\mathrm{g})$ & 30 & 30 & 30 \\
Refined salt $(\mathrm{g})$ & 9 & 9 & 9 \\
Egg $(\mathrm{g})$ & 200 & 200 & 200 \\
Orafti ${ }^{\circ} \mathrm{GR}(\mathrm{g})$ & - & $130^{*}$ & - \\
Orafti ${ }^{\text {Synnergy1 }}(\mathrm{g})$ & - & - & $175^{* *}$ \\
\hline
\end{tabular}

*Equivalent to $20 \%$ in relation to the wheat flour and $8.8 \%$ in relation to the bread dough; ${ }^{* *}$ Equivalent to $27 \%$ in relation to the wheat flour and $11.5 \%$ in relation to the bread dough. 


\subsection{Descriptive analysis of the bread samples}

The study was approved by the Ethics in Research Committee of the Institute of Biosciences, Literature and Exact Sciences (Ibilce) of São Paulo State University (Unesp), Brazil (Decision No. 029/10).

The sensory analysis was carried out in the Sensory Analysis Laboratory of the Department of Food Engineering and Technology of Ibilce/Unesp. Panellists were recruited from amongst the students and staff, and the descriptive analysis was based on an adaptation of that provided by Stone and Sidel (1993).

Of the thirty-two panellists recruited, Thirteen were preselected using a basic taste recognition test (minimum of 6 correct responses from a total of 9 solutions; MEILGAARD et al., 2007); an odour recognition test (minimum of 6 correct responses from a total of 8 odours: wheat flour, yeast, bread, toasted bread, sweet bread, vanilla, whole grain bread and egg; MEILGAARD et al., 2007); and a difference from control test with three repetitions in relation to the degree of sweetness, which is an important parameter of bread with fructans. The panellists were preselected based on their capacity to discriminate the samples $\left(p_{\text {sample }} \leq 0.50\right)$ and on their capacity to reproduce their judgments $\left(p_{\text {repetition }}>0.05\right)$ (ASTM, 1981; DAMÁSIO; COSTELL, 1991).

The descriptive terms were generated by the thirteen panellists using the Kelly Repertory Grid method (MOSKOWITZ, 1983). Descriptive terms that were more important to characterize the appearance, aroma, texture and flavour of the bread were selected. The sensory panel also defined the descriptive terms, the references for each, and the product evaluation form (Table 2).

During the training stage, which required ten sessions, the panellists were selected according to their discriminative capacity $\left(p_{\text {sample }} \leq 0.50\right)$, reproducibility capacity $\left(p_{\text {repetition }} \geq 0.05\right)$, and consensus with the panel (ASTM, 1981; DAMÁSIO; COSTELL, 1991). Nine of the thirteen panellists, who carried out the analyses of the sensory profiles of the bread, were selected, the final sensory panel being composed of women between 21 and 29 years of age.

Table 2. Definitions and references for the descriptive terms used for the bread

\begin{tabular}{|c|c|c|}
\hline Descriptive Term & Definition & Reference \\
\hline \multicolumn{3}{|l|}{ Appearance } \\
\hline \multirow{2}{*}{ Beige colour of the crust } & \multirow{2}{*}{$\begin{array}{l}\text { Degree of beige colour similar to that of a } \\
\text { normal bread crust }\end{array}$} & \\
\hline & & High: whole grain bread crust (Wickbold) \\
\hline \multirow{2}{*}{ White-yellow colour of the crumb } & \multirow{2}{*}{$\begin{array}{l}\text { Degree of white-yellow colour similar to that } \\
\text { of normal bread crumb }\end{array}$} & Low: wheat flour (Dona Benta) \\
\hline & & High: industrialized milk flour (Nestlé) \\
\hline & & Low: crust of Brazilian-style French bread \\
\hline Crust uniformity & Homogeneity of the crust & $\begin{array}{l}\text { High: industrialized Brazilian bread rolls } \\
\text { (Pullman) }\end{array}$ \\
\hline \multirow{2}{*}{ Bubble size } & \multirow{2}{*}{$\begin{array}{l}\text { Size of the cavities in the crumb formed by } \\
\text { air bubbles }\end{array}$} & Small: commercial coconut cake (Pullman) \\
\hline & & Large: panettone (Pão de Açúcar) \\
\hline \multicolumn{3}{|c|}{ 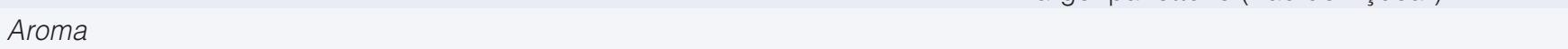 } \\
\hline \multirow{2}{*}{ Homemade-bread-like aroma } & \multirow{2}{*}{ Characteristic aroma of homemade bread } & Low: Brazilian dinner rolls (Pullman) \\
\hline & & High: corn bread (Panco) \\
\hline & & Low: Brazilian dinner rolls (Pullman) \\
\hline Yeast aroma & Characteristic aroma of fermented products & $\begin{array}{l}\text { High: biological yeast (Fleischmann) diluted } \\
\text { in water }(1: 10)\end{array}$ \\
\hline \multicolumn{3}{|l|}{ Texture } \\
\hline \multirow{2}{*}{ Softness } & \multirow{2}{*}{$\begin{array}{l}\text { Force necessary to compress the sample } \\
\text { between the teeth }\end{array}$} & Low: bread enriched with omega (Nutrella) \\
\hline & & High: white bread without crust (Wickbold) \\
\hline & & Low: jellow (Carrefour) \\
\hline Chewiness & Ease of masticating and swallowing the food & $\begin{array}{l}\text { High: dry Brazilian biscuits (sequilho) } \\
\text { (Topday) }\end{array}$ \\
\hline \multicolumn{3}{|l|}{ Flavour } \\
\hline \multirow{2}{*}{ Homemade-bread-like flavour } & \multirow{2}{*}{ Characteristic flavour of homemade bread } & Low: Brazilian dinner rolls (Pullman) \\
\hline & & High: corn bread (Panco) \\
\hline \multirow{2}{*}{ Sweetness } & \multirow{2}{*}{ Characteristic taste of sucrose solution } & Low: $1 \%$ sucrose solution in water \\
\hline & & High: $10 \%$ sucrose solution in water \\
\hline
\end{tabular}


The sensory analysis was carried out in individual booths under white light at a temperature of $22{ }^{\circ} \mathrm{C}$. The bread samples were presented on plastic plates coded with random three-digit numbers and evaluated with four repetitions by the nine panellists. The sample presentation was balanced using complete blocks that were randomized and monadic, and an unstructured linear intensity scale of $90 \mathrm{~mm}$ in length was used for each descriptive term presented in Table 2.

\subsection{Evaluation of sensory acceptability of the bread}

The sensory test was carried out in the Sensory Analysis Laboratory the Department of Food Engineering and Technology of Ibilce/Unesp, Using individual booths illuminated with white light. Students, staff and professors were recruited for the sensory analysis, forming the untrained sensory panel.

First, a questionnaire was filled in to characterize the consumers (age and sex), the extent to which they liked bread, their preferences with respect to type of bread, and their consumption habits. The bread formulations were evaluated using a nine-point hedonic scale ( 1 = disliked extremely, 5 = neither liked nor disliked, 9 = liked extremely) based on appearance, aroma, texture, flavour and overall acceptability. The consumers were also asked to rate the appropriateness of the bread sweetness using a nine-point just-about-right scale ( 1 = extremely less sweet than ideal, 5 = ideal sweetness, 9 = extremely more sweet than ideal) (MEILGAARD et al., 2007).

The test was carried out on fifty consumers, and the samples randomized and evaluated in a monadic manner with a complete and balanced block design (MACFIE et al., 1989). The consumers received a sample of each bread sample on a napkin encoded with random three digits.

\subsection{Statistical analysis}

The mean values for the descriptive terms and sensory acceptability of the bread samples scored using the nine-point hedonic scale were compared using the variance analysis followed by Tukey's test (significant difference set at $p \leq 0.05$ ).

The internal preference mapping for overall acceptability was constructed using multivariate analyses: cluster analysis and multidimensional scaling (MDS). For this purpose the bread formulations were placed in columns (variables) and the individual scores in rows (cases). First, a joining cluster analysis using Euclidean distances as the distance measurements and the single linkage method as the amalgamation rule was applied to the individual data from each consumer, and the midpoint of the major increment used to separate the groups. Multidimensional scaling analysis was then applied to the matrix resulting from the cluster analysis.

All statistical analyses were carried out using the Statistica 10.0 software (StatSoft Inc., Oklahoma, USA).

\section{Results and discussion}

\subsection{Sensory profiles of the bread samples}

The sweetness intensity was the only term that discriminated the bread samples, decreasing from the bread with oligofructose/inulin to the bread with inulin and finally to the standard bread (Table 3). Fructans are fructose polymers linked by linear or branched connections through $\beta(2 \rightarrow 1)$ or $\beta(2 \rightarrow 6)$ (CARABIN; FLAMM, 1999; MORRIS; MORRIS, 2012), and the inulin produces a neutral mild flavour while oligofructose is moderately sweet, with a sweetness power near that of sucrose (FRANCK, 2002). The sweetness power of oligofructose and the quantities of glucose + fructose + sucrose in inulin justify the higher sweetness intensities of bread with oligofructose/inulin and with inulin, respectively, when compared to the standard bread.

The crust of the bread with inulin presented greater colour intensity than that of the standard bread (Table 3), which may be the result of the Maillard reaction that occurred because of the fructose molecules present in the inulin chains (CARABIN; FLAMM, 1999; DAMODARAN et al., 2008; MORRIS; MORRIS, 2012). In addition, the bread with

Table 3. Intensity of the descriptive terms for the bread (mean $\pm S D, n=36$ )

\begin{tabular}{|c|c|c|c|}
\hline Descriptive Term & Standard & Inulin & Oligofructose/Inulin \\
\hline Beige colour of the crust & $4.3 \pm 1.8^{a}$ & $5.2 \pm 1.5^{b}$ & $4.7 \pm 1.6^{\mathrm{ab}}$ \\
\hline White-yellow colour of the crumb & $4.5 \pm 1.8^{\text {ns }}$ & $4.4 \pm 1.6^{\text {ns }}$ & $4.2 \pm 1.7^{\mathrm{ns}}$ \\
\hline Crust uniformity & $7.0 \pm 1.3^{\text {ns }}$ & $7.3 \pm 1.1^{\mathrm{ns}}$ & $6.8 \pm 1.5^{\text {ns }}$ \\
\hline Bubble size & $4.3 \pm 2.1^{b}$ & $3.5 \pm 1.7^{\mathrm{ab}}$ & $3.0 \pm 1.8^{a}$ \\
\hline Homemade-bread-like aroma & $4.0 \pm 1.8^{\text {ns }}$ & $4.1 \pm 1.7^{\mathrm{ns}}$ & $3.8 \pm 1.9^{\text {ns }}$ \\
\hline Yeast aroma & $1.3 \pm 0.7^{\mathrm{ns}}$ & $1.4 \pm 0.9^{\text {ns }}$ & $1.4 \pm 0.9^{\text {ns }}$ \\
\hline Softness & $6.1 \pm 1.0^{\mathrm{b}}$ & $5.9 \pm 1.2^{b}$ & $5.1 \pm 1.3^{a}$ \\
\hline Chewiness & $4.9 \pm 1.6^{\text {ns }}$ & $4.9 \pm 1.6^{\text {ns }}$ & $5.4 \pm 1.7^{\mathrm{ns}}$ \\
\hline Homemade-bread-like flavour & $3.4 \pm 1.5^{\mathrm{ns}}$ & $4.0 \pm 1.7^{\mathrm{ns}}$ & $4.0 \pm 1.7^{\mathrm{ns}}$ \\
\hline Sweetness & $1.5 \pm 0.9^{a}$ & $3.6 \pm 1.9^{b}$ & $4.5 \pm 1.9^{c}$ \\
\hline
\end{tabular}

Different letters in the same line indicate different means according to Tukey's test ( $p \leq 0.05$ ); ns = not significant. 
oligofructose/inulin had smaller bubbles and was less soft than the standard bread (Table 3). It is important to note that both the smaller bubble size and the decrease in softness might have been the result of more limited expansion of the bread. Fructans are soluble fibres, compounds that can impair the texture of baked goods (POMERANZ et al., 1977; WANG et al., 2002). Higher concentrations of inulin have resulted in greater bread crumb hardness values relative to those of bread containing fat (O'BRIEN et al., 2003), and oligofructose has been found to enhance the firmness of sponge cake relative to cake with sucrose (RONDA et al., 2005).

The three bread samples were very similar, since there was no difference in most of the descriptive terms (Table 3): the white-yellow colour of the crumb, crust uniformity, homemade-bread-like aroma, yeast aroma, chewiness, and homemade-bread-like flavour. Although the literature tends to report an increase in aroma and flavour when fructans are added (ARCIA et al., 2011; SENDRA et al., 2008; TÁRREGA et al., 2010), the aroma and flavour were apparently not affected by the addition of these products in this study. Similar to the results found in the present study, other authors found that the addition of prebiotic ingredients to bakery products resulted in a similar flavour to the control products (ARMSTRONG et al., 2009; VOLPINI-RAPINA et al., 2012).

\subsection{Sensory acceptability of the bread samples}

Most of the fifty consumers were female and between 18 and 27 years of age, consumed bread daily and liked bread a lot. The preferences for bread included Brazilian-style French bread, followed by Brazilian homemade-style bread (pão caseiro), Brazilian industrialized bread rolls (bisnaguinha), whole grain bread, white bread and Brazilian dinner rolls (pão de leite).

The bread formulations tested showed equal degrees of liking in relation to appearance, aroma and texture; however, the bread with oligofructose/inulin received higher scores for flavour and overall acceptability as compared to the standard bread (Table 4). In general, the degree of liking for the bread in this study was higher than the scores given to bread and bakery products with added fructans in other studies (DEVEREUX et al., 2003;

Table 4. Sensory acceptability scores for the standard bread, that with inulin and that with oligofructose/inulin (mean $\pm S D, n=50$ ).

\section{Standard Inulin Oligofructose/Inulin}

\begin{tabular}{llll} 
Appearance & $7.7 \pm 1.1^{\mathrm{ns}}$ & $7.8 \pm 1.0^{\mathrm{ns}}$ & $8.0 \pm 1.0^{\mathrm{ns}}$ \\
Aroma & $6.9 \pm 1.6^{\mathrm{ns}}$ & $7.4 \pm 1.4^{\mathrm{ns}}$ & $7.4 \pm 1.6^{\mathrm{ns}}$ \\
Texture & $7.3 \pm 1.3^{\mathrm{ns}}$ & $7.2 \pm 1.5^{\mathrm{ns}}$ & $7.7 \pm 1.2^{\mathrm{ns}}$ \\
Flavour & $6.8 \pm 1.8^{\mathrm{a}}$ & $7.4 \pm 1.3^{\mathrm{ab}}$ & $7.6 \pm 1.2^{\mathrm{b}}$ \\
Overall & $7.0 \pm 1.6^{\mathrm{a}}$ & $7.6 \pm 1.0^{\mathrm{ab}}$ & $7.8 \pm 1.0^{\mathrm{b}}$ \\
\hline
\end{tabular}

Different letters in the same line indicate different means according to Tukey's test $(p \leq 0.05) ; \mathrm{ns}=$ not significant.
RODRÍGUEZ-GARCÍA et al., 2012; RONDA et al., 2005; WANG et al., 2002).

The multidimensional scaling analysis is a multivariate technique based on the proximities between objects, subjects or stimuli, which is used to produce a spatial representation of these items (HAIR et al., 2006) and which results in internal preference mapping. Multidimensional scaling can be evaluated in terms of the stress value: values below 0.05 indicate that the use of this multivariate analysis is appropriate (JOHNSON; WICHERN, 1992; KRUSKAL; WISH, 1978). In the present study, all the internal preference maps were found to have stress values below 0.001 .

The cluster analysis and internal preference mapping constructions were similar for the sensory attributes and overall acceptability of the bread samples so only the results for overall acceptability were shown. The cluster analysis for overall acceptability (Figure $1 \mathrm{~A}$ ) resulted in two groups: one group that included the standard bread, and another group with the inulin and oligofructose/inulin bread. The scattered points presented in the internal preference mapping for overall acceptability (Figure 1B) represent each consumer, and the number of points near a given sample or near a group of samples indicates the acceptability scores for these samples. In the present case, there was a higher concentration of consumers around the group containing the inulin and oligofructose/inulin bread, indicating that the consumers liked these samples. Therefore, although Table 4 shows similarities in degree of liking for the standard bread and that with inulin, both bread samples with fructans were preferred by the consumers over the standard bread in terms of the attributes and overall acceptability (Figure 1).

When the sweetness intensity was evaluated, the bread with inulin was more frequently chosen as having an ideal sweetness intensity, followed by the bread with oligofructose/inulin and lastly by the standard bread (Figure 2). It is important to note that the consumers gave a high frequency of less than ideal sweetness scores to the standard bread. The addition of fructans resulted in higher frequencies of scores given for the ideal sweetness and above ideal sweetness options. Interestingly, although consumers reported that the sweetness of the bread with oligofructose/inulin was above the ideal, the degree of liking for flavour was higher for this bread than for the standard bread (Table 4).

Considering the results for the sensory profiles and acceptability, the differences in intensity of the beige colour of the crust, bubble size and softness (Table 3) did not affect the degree of liking in terms of bread appearance or texture (Table 4). However, the difference in degree of liking based on bread flavour may have been the result of different sweetness intensities, a finding which coincided 
Sensory profile and evaluation of the degree of acceptability of bread produced with inulin and oligofructose Souza-Borges, P. K.; Conti-Silva, A. C.
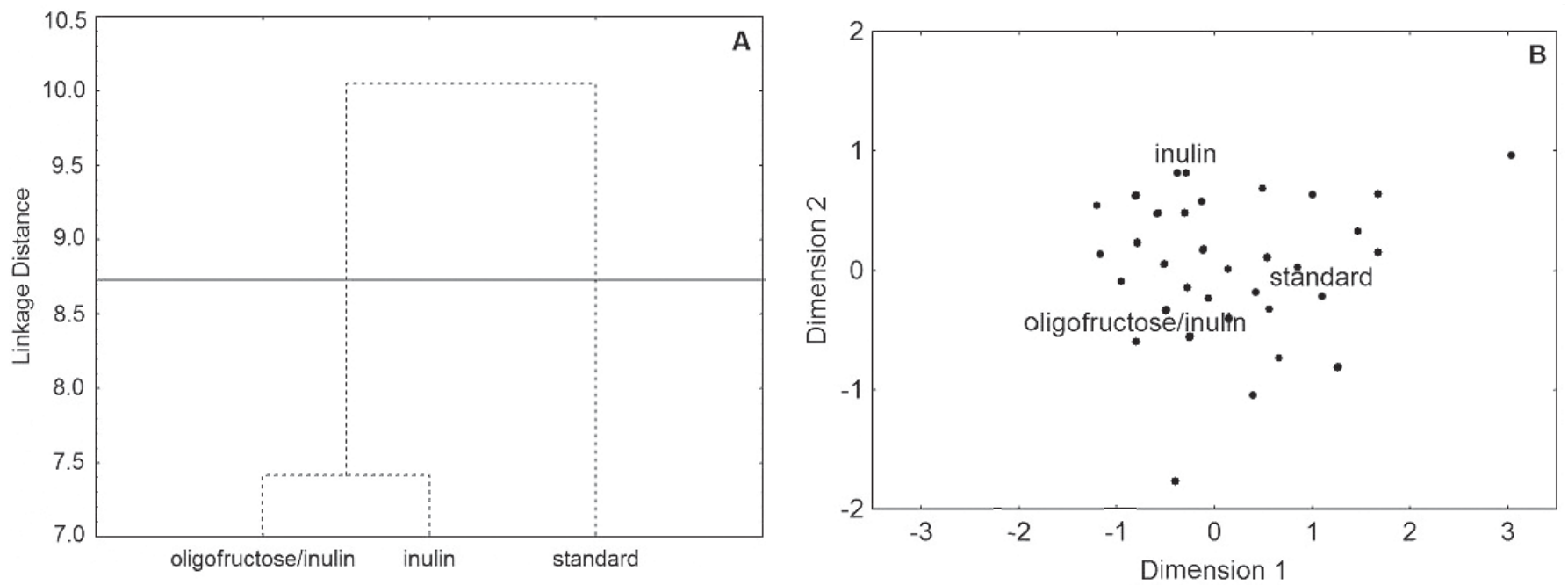

Figure 1. Dendogram $(A)$ and internal preference mapping $(B)$ for the overall acceptability of the bread samples.

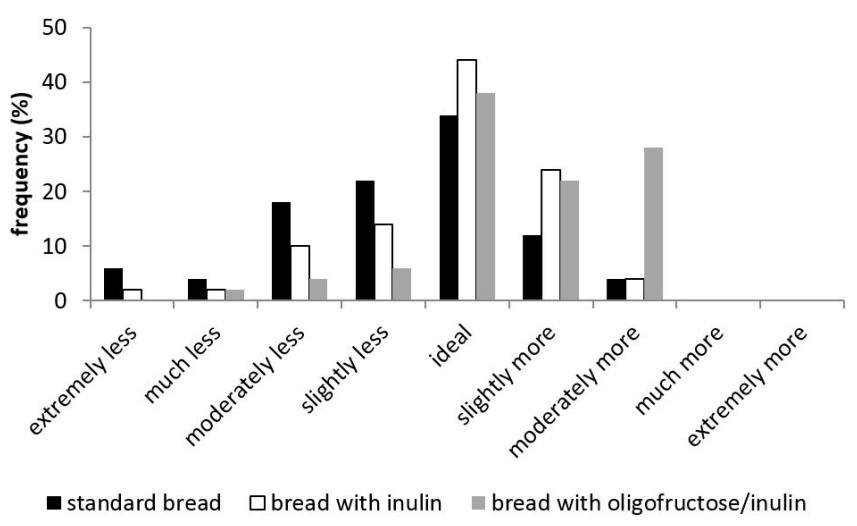

Figure 2. Frequency distribution of the consumer responses on the just-about-right scale.

with the ideal sweetness most frequently reported for bread with fructans (Figure 2).

\section{Conclusions}

The sensory profiles of the bread samples used in the present study were very similar, and differences were found in terms of the beige colour of the crust, the size of the bubbles, softness and sweetness. The bread with oligofructose/inulin was found to have a greater degree of liking in terms of flavour and overall acceptability than the standard bread, but both bread samples with fructans were preferred over the standard bread when appearance, aroma, texture, flavour and overall acceptability were taken into account. In conclusion, the addition of fructans to bread is promising and may promote the consumption of a potentially prebiotic product.

\section{Acknowledgements}

The authors are grateful for the financial support received from the São Paulo State Research Foundation (FAPESP; Grant No. 2010/00996-0), from The Department of Research at the São Paulo State University (Pró-Reitoria de Pesquisa da UNESP) and for the inulin and oligofructose provided by Beneo-Orafti.

\section{References}

AGÊNCIA NACIONAL DE VIGILÂNCIA SANITÁRIA - ANVISA. Alimentos com alegações de propriedades funcionais e ou de saúde. Brasília: ANVISA, 2016. Available at: < http://portal. anvisa.gov.br/alimentos/alegacoes>. Accessed on: 19 feb. 2016.

AMERICAN SOCIETY FOR TESTING AND MATERIALS - ASTM. Guidelines for the selection and training of sensory panel members. Philadelphia: ASTM, 1981. 35 p. (STP, 758).

ARCIA, P. L.; COSTELL, E.; TÁRREGA, A. Inulin blend as prebiotic and fat replacer in dairy desserts: optimization by response surface methodology. Journal of Dairy Science, v. 94, n. 5, p. 2192-2200, 2011. PMid:21524509. http://dx.doi.org/10.3168/ jds.2010-3873.

ARMSTRONG, L. M.; LUECKE, K. J.; BELL, L. N. Consumer evaluation of bakery product flavour as affected by incorporating the prebiotic tagatose. International Journal of Food Science \& Technology, v. 44, n. 4, p. 815-819, 2009. http://dx.doi. org/10.1111/j.1365-2621.2009.01909.x.

CAPRILES, V. D.; ARÊAS, J. A. G. Effects of prebiotic inulin-type fructans on structure, quality, sensory acceptance and glycemic response of gluten-free breads. Food \& Function, v. 4, n. 1, p. 104-110, 2013. PMid:23032642. http://dx.doi.org/10.1039/ $\mathrm{C} 2 \mathrm{FO} 10283 \mathrm{H}$.

CARABIN, I. G.; FLAMM, W. G. Evaluation of safety of inulin and oligofructose as dietary fiber. Regulatory Toxicology and Pharmacology, v. 30, n. 3, p. 268-282, 1999. PMid:10620476. http://dx.doi.org/10.1006/rtph.1999.1349.

DAMÁSIO, M. H.; COSTELL, E. Análisis sensorial descriptivo: generación de descriptores y selección de catadores. Revista 
Sensory profile and evaluation of the degree of acceptability of bread produced with inulin and oligofructose Souza-Borges, P. K.; Conti-Silva, A. C.

de Agroquímica y Tecnología de Alimentos, v. 31, n. 2, p. 165-178, 1991

DAMODARAN, S.; PARKIN, K. L.; FENNEMA, O. R. Fennema's food chemistry. 4th ed. Boca Raton: CRC Press, 2008. $1160 \mathrm{p}$.

DEVEREUX, H. M.; JONES, G. P.; MCCORMACK, L.; HUNTER, W. C. Consumer acceptability of low fat foods containing inulin and oligofructose. Journal of Food Science, v. 68, n. 5, p. 1850-1854, 2003. http://dx.doi.org/10.1111/j.1365-2621.2003. tb12341.x.

FRANCK, A. Technological functionality of inulin and oligofructose. British Journal of Nutrition, v. 87, p. S287-S291, 2002. Supplement 2. PMid:12088531. http://dx.doi.org/10.1079/BJN/2002550.

GIBSON, G. R.; ROBERFROID, M. B. Dietary modulation of the human colonic microbiota: introducing the concept of prebiotics. The Journal of Nutrition, v. 125, n. 6, p. 1401-1412, 1995. PMid:7782892.

HAIR, J. F.; BLACK, B.; BABIN, B.; ANDERSON, R. E.; TATHAM, R. L. Multivariate data analysis. 6th ed. New Jersey: Prentice Hall, 2006. 928 p.

JOHNSON, R. A.; WICHERN, D. W. Applied multivariate statistical analysis. 3rd ed. Englewood Cliffs: Prentice Hall, 1992. 642 p.

JOUSSE, F. Modeling to improve the efficiency of product and process development. Comprehensive Reviews in Food Science and Food Safety, v. 7, n. 1, p. 175-181, 2008. http:// dx.doi.org/10.1111/j.1541-4337.2007.00033.x

KORUS, J.; GRZELAK, K.; ACHREMOWICZ, K.; SABAT, R. Influence of prebiotic additions on the quality of gluten-free bread and on the content of inulin and fructoooligosaccharides. Food Science \& Technology International, v. 12, n. 6, p. 489-495, 2006. http://dx.doi.org/10.1177/1082013206073072.

KRUSKAL, J. B.; WISH, M. Multidimensional scaling. Newbury Park: Sage, 1978. 93 p. http://dx.doi.org/10.4135/9781412985130.

LAMSAL, B.; FAUBION, J. The beneficial use of cereal and cereal components in probiotic foods. Food Reviews International, v. 25, n. 2, p. 103-114, 2009. http://dx.doi.org/10.1080/87559120802682573.

MACFIE, H. J.; BRATCHELL, N.; GREENHOFF, K.; VALLIS, L. $V$. Designs to balance the effect of order of presentation and first-order carry-over effects in hall tests. Journal of Sensory Studies, v. 4, n. 2, p. 129-148, 1989. http://dx.doi.org/10.1111/ j.1745-459X.1989.tb00463.x.

MEILGAARD, M.; CIVILLE, G. V.; CARR, B. T. Sensory evaluation techniques. 4th ed. Boca Raton: CRC Press, 2007. $464 \mathrm{p}$

MORRIS, C.; MORRIS, G. A. The effect of inulin and fructooligosaccharide supplementation on the textural, rheological and sensory properties of bread and their role in weight management: a review. Food Chemistry, v. 133, n. 2, p. 237-248, 2012. PMid:25683391. http://dx.doi.org/10.1016/j.foodchem.2012.01.027.
MOSKOWITZ, H. R. Product testing and sensory evaluation of foods. Westport: Food \& Nutrition Press, 1983. 605 p.

O'BRIEN, C. M.; MUELLER, A.; SCANNELL, A. G. M.; ARENDT, E. K. Evaluation of the effects of fat replacers on the quality of wheat bread. Journal of Food Engineering, v. 56, n. 2-3, p. 265-267, 2003. http://dx.doi.org/10.1016/S0260-8774(02)00266-2.

POMERANZ, Y.; SHOGREN, M.; FINNEY, K. F.; BECHTEL, D. B. Fibre in breadmaking-effects on functional properties. Cereal Chemistry, v. 54, p. 25-41, 1977.

ROBERFROID, M. B. Introducing inulin-type fructans. British Journal of Nutrition, v. 93, p. S13-S25, 2005. Supplement 1. PMid:15877886. http://dx.doi.org/10.1079/BJN20041350.

ROBERFROID, M. B.; DELZENNE, N. Dietary fructans. Annual Review of Nutrition, v. 18, n. 1, p. 117-143, 1998. PMid:9706221. http://dx.doi.org/10.1146/annurev.nutr.18.1.117.

RODRÍGUEZ-GARCÍA, J.; PUIG, A.; SALVADOR, A.; HERNANDO, I. Optimization of a sponge cake formulation with inulin as fat replacer: structure, physicochemical, and sensory properties. Journal of Food Science, v. 77, n. 2, p. C189-C197, 2012. PMid:22250810. http://dx.doi.org/10.1111/j.1750-3841.2011.02546.x. RONDA, F.; GÓMEZ, M.; BLANCO, C. A.; CABALLERO, P. A. Effects of polyols and nondigestible oligosaccharides on the quality of sugar-free sponge cakes. Food Chemistry, v. 90, n. 4, p. 549-555, 2005. http://dx.doi.org/10.1016/j.foodchem.2004.05.023.

SENDRA, E.; FAYOS, P.; LARIO, Y.; FERNÁNDEZ-LÓPEZ, J.; SAYAS-BARBERÁ, E.; PÉREZ-ALVAREZ, J. A. Incorporation of citrus fibers in fermented milk containing probiotic bacteria. Food Microbiology, v. 25, n. 1, p. 13-21, 2008. PMid:17993372. http://dx.doi.org/10.1016/j.fm.2007.09.003.

SIRÓ, I.; KÁPOLNA, E.; KÁPOLNA, B.; LUGASI, A. Functional food. Product development, marketing and consumer acceptance - A review. Appetite, v. 51, n. 3, p. 456-467, 2008. PMid: 18582508. http://dx.doi.org/10.1016/j.appet.2008.05.060.

SOUZA-BORGES, P. K.; SOKEI, F. R.; SPAGNOL, T. D.; CONTISILVA, A. C. Características químicas, físicas e sensoriais de bolos de laranja e pães adicionados de inulina e oligofrutose. Semina: Ciências Agrárias, v. 34, n. 6, p. 2837-2846, 2013. http://dx.doi.org/10.5433/1679-0359.2013v34n6p2837.

STONE, H.; SIDEL, J. L. Sensory evaluation practices. 2nd ed. San Diego: Academic Press, 1993. 338 p.

TÁRREGA, A.; ROCAFULL, A.; COSTELL, E. Effect of blends of short and long-chain inulin on the rheological and sensory properties of prebiotic low-fat custards. Lebensmittel-Wissenschaft + Technologie, v. 43, n. 3, p. 556-562, 2010. http://dx.doi. org/10.1016/j. Iwt.2009.10.002.

TUORILA, H.; CARDELLO, A. V. Consumer responses to an off-flavor in juice in the presence of specific health claims. Food 
Sensory profile and evaluation of the degree of acceptability of bread produced with inulin and oligofructose Souza-Borges, P. K.; Conti-Silva, A. C.

Quality and Preference, v. 13, n. 7-8, p. 561-569, 2002. http:// dx.doi.org/10.1016/S0950-3293(01)00076-3.

VOLPINI-RAPINA, L. F.; SOKEI, F. R.; CONTI-SILVA, A. C. Sensory profile and preference mapping of orange cakes with addition of prebiotics inulin and oligofructose. LebensmittelWissenschaft + Technologie, v. 48, n. 1, p. 37-42, 2012. http:// dx.doi.org/10.1016/j.Iwt.2012.03.008.
WANG, J.; ROSELL, C. M.; BARBER, C. B. Effect of the addition of different fibres on wheat dough performance and bread quality. Food Chemistry, v. 79, n. 2, p. 221-226, 2002. http://dx.doi. org/10.1016/S0308-8146(02)00135-8.

WANG, Y. Prebiotics: present and future in food science and technology. Food Research International, v. 42, n. 1, p. 8-12, 2009. http://dx.doi.org/10.1016/j.foodres.2008.09.001. 